Junot Díaz and the Decolonial Imagination 


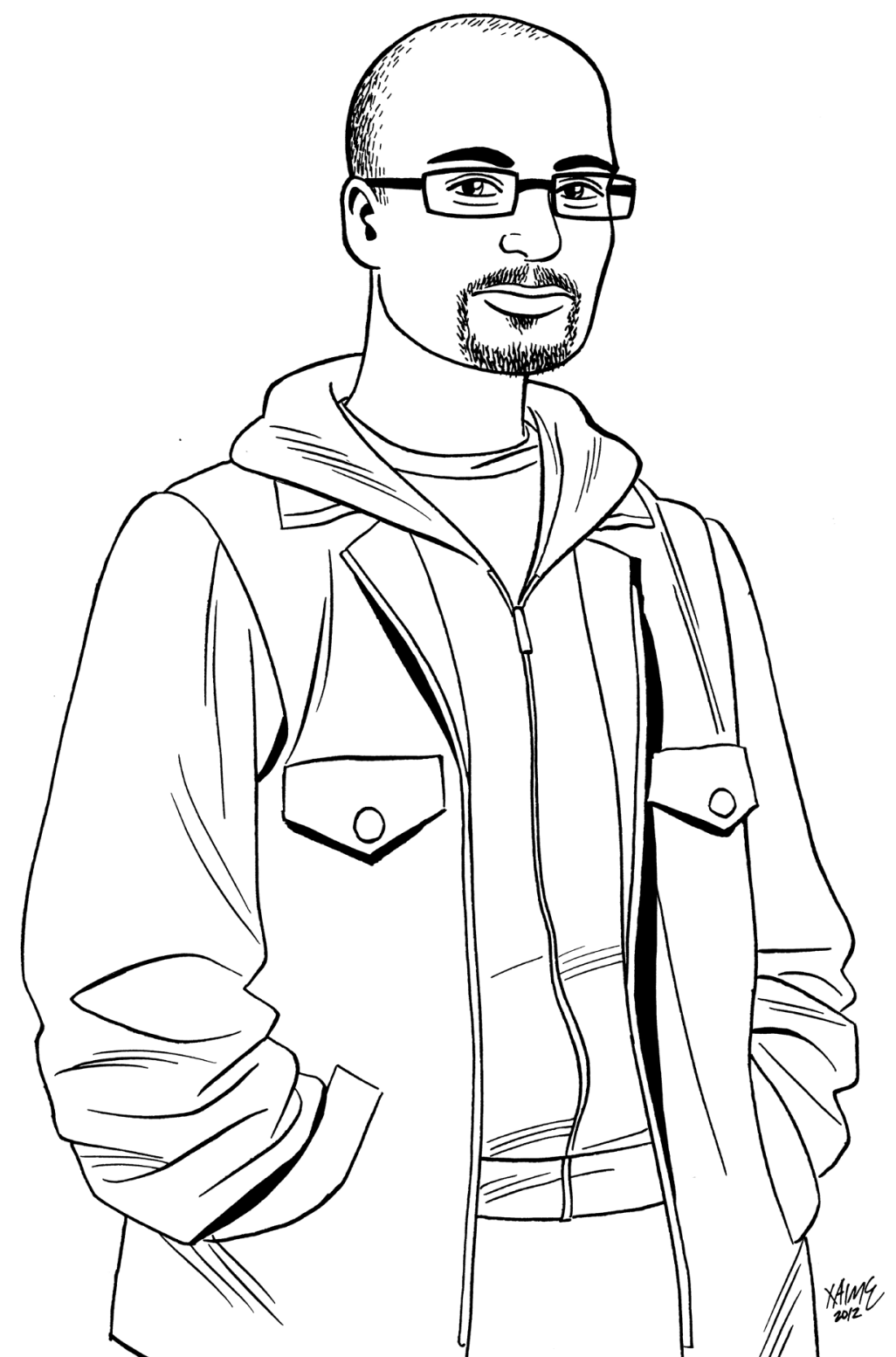




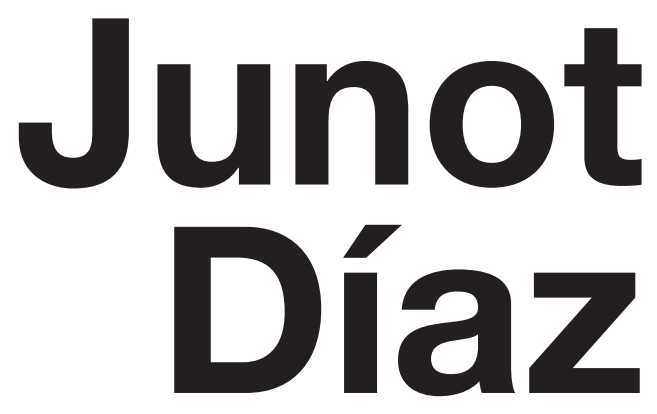

\title{
and the Decolonial Imagination
}

\author{
MONICA HANNA, \\ JENNIFER HARFORD VARGAS, \\ and JOSÉ DAVID SALDÍVAR, Editors
}


() 2016 Duke University Press

All rights reserved

Printed in the United States of America on acid-free paper $\infty$

Designed by Natalie F. Smith

Typeset in Quadraat Pro by Westchester Publishing Services

Library of Congress Cataloging-in-Publication Data

Junot Díaz and the decolonial imagination / edited by Monica Hanna, Jennifer Harford Vargas, and José David Saldívar.

pages $\mathrm{cm}$

Includes bibliographical references and index.

ISBN 978-o-8223-6024-7 (hardcover : alk. paper)

ISBN 978-o-8223-6033-9 (pbk. : alk. paper)

ISBN 978-o-8223-7476-3 (e-book)

I. Díaz, Junot, [date]-Criticism and interpretation. 2. Decolonization

in literature. I. Hanna, Monica, editor. II. Harford Vargas, Jennifer,

[date] editor. III. Saldívar, José David, editor.

PS3554.I259Z75 2016

$813^{\prime} \cdot 54$-dc23

2015026284

Cover art: Line drawing of Junot Díaz by Jaime Hernandez. Illustration coloring and background art by Andrew H. Leung.

Portions of Chapter 6 were published in Neocolonialism and Cultural Memory: Narrative in Chicana/o and Latina/o Fiction. Used with permission of the University of Illinois Press. Chapter 8 was published in an earlier form in MELUS: Multi-Ethnic Literature of the United States 39, no. 3 (fall 2014): 8-30. Chapter 9 was published, in a slightly modified version, in The Social Imperative: Race, Close Reading, and Contemporary Literary Criticism by Paula Moya, @ 2016 by the Board of Trustrees of the Leland Stanford Jr. University. All Rights reserved. Used with the permission of Stanford University Press; www.sup .org. Chapter 15 was originally published in The Boston Review, June 26, 2012. Reprinted with permission. 